Al-Manhaj: Jurnal Hukum dan Pranata Sosial Islam

Vol. : : 1 (2), 2019, 177-196

P-ISSN : 2686-1607

E-ISSN : 2686-4819

\title{
PENGELOLAAN BANK SAMPAH SEBAGAI UPAYA PEMBERDAYAAN MASYARAKAT DALAM PERSPEKTIF MAQASHID AL-SYARI'AH: Studi Kasus di Bank Sampah Srikandi Dolopo Madiun
}

\author{
Dwi Runjani Juwita \\ Sekolah Tinggi Agama Islam Nahdlatul Ulama' Madiun \\ email: dwi.runjani@gmail.com
}

\begin{abstract}
Waste is a trivial thing, even considered dirty and disgusting. When the waste is held by people who do not know how to manage it, this will be a very big and complicated problem. But on the contrary, when the waste is held and managed properly and correctly by people who understand, then the waste will become something very valuable. The Srikandi Waste Bank, which was established in 2015, is a place where people can save waste, then it will be transformed into something very valuable can even make money. With the establishment of the Srikandi Waste Bank, it launched handicraft products from Dolopo which produced from waste materials that had been recycled. With the existence of a Waste Bank, it also helps in empowering the community of housewives who do not have permanent jobs. The results of this study are: that there are many benefits that can be obtained from the existence of a Waste Bank such as a savings system, profit sharing cooperation, reduce unemployment, and cleanliness of the environment.
\end{abstract}

Keywords: Waste Bank, Community Empowerment, Maqasid al-Syariah

Abstrak: Sampah merupakan hal yang sepele,bahkan dianggap kotor dan
menjijikkan. Ketika dipegang oleh orang-orang yang tidak mengetahui
bagaimana mengelola sampah maka hal ini akan menjadi permasalahan
yang sangat besar dan kompleks. Tapi sebaliknya, ketika sampah
dipegang oleh orang-orang yang mengetahui dan dikelola dengan baik
dan benar, maka sampah akan menjadi sesuatu yang sangat berharga 
bahkan menjadi barang yang bernilai ekonomis. Bank Sampah Srikandi yang berdiri sejak tahun 2015 adalah sebuah tempat dimana masyarakat bisa menabung sampah yang nantinya sampah tersebut akan disulap menjadi sesuatu yang sangat berharga bahkan bisa menghasilkan uang.Dengan berdirinya Bank Sampah Srikandi ini muncul berbagai produk kreatif dari warga Dolopo yang dihasilkan dari bahan dasar sampah yang telah didaur ulang. Dengan adanya Bank Sampah ini juga membantu dalam pemberdayaan masyarakat terutama para ibu-ibu rumah tangga yang tidak mempunyai pekerjaan tetap. Hasil dari penelitian ini adalah, terdapat banyak manfaat yang bisa diperoleh dari adanya bank sampah seperti sistem tabungan, kerja sama bagi hasil, mengurangi pengangguran serta kebersihan lingkungan hidup.

Kata Kunci: Bank Sampah, Pemberdayaan masyarakat, Maqasid alSyariah

\section{PENDAHULUAN}

Menurut Peraturan Menteri Negara Lingkungan Hidup Republik Indonesia Nomor 13 Tahun 2012 Tentang Pedoman Pelaksanaan Reduce, Reuse dan Recycle Melalui Bank Sampah, pada pasal 1 disebutkan bahwa Bank Sampah adalah tempat pemilahan dan pengumpulan sampah yang dapatdidaur ulang dan / atau diguna ulang yang memiliki nilai ekonomi. ${ }^{1}$

Sedangkan Bank Sampah menurut Unilever adalah suatu system pengelolaan sampah kering secara kolektif yang mendorong masyarakat untuk berperan serta aktif didalamnya. Sistem ini akan menampunng,memilah dan menyalurkan sampah bernilai ekonomi pada pasar sehingga masyarakat mendapat keuntungan ekonomi dari menabung sampah. ${ }^{2}$

\footnotetext{
1Peraturan Menteri Negara Lingkungan Hidup Republik Indonesia Nomor 13 tahun 2012 tentang Pedoman Pelaksanaan Reduce, Reuse, dan Recycle Melalui Bank Sampah.

2 Unilever indonesia, Buku Panduan Sistem Bank Sampah dan 10 Kisah Sukses (Jakarta: Unilever, 2014), 3.
} 
Pada umumnya Bank merupakan sebuah instansi yang bergerak dibidang penyimpanan uang, namun belakangan ini Bank digunakan untuk menyimpan sampah masyarakat sekitar dan mengelola sampah tersebut menjadi uang.

Tujuan dibangunnya Bank sampah adalah untuk menangani pengolahan sampah di lingkungan masyarakat. Selanjutnya yaitu untuk menyadarkan masyarakat akan lingkungan yang sehat, rapi dan bersih, Bank Sampah didirikan juga untuk mengurangi pengangguran dan memberdayakan masyarakat yang tidak mempunyai pekerjaan tetap. Bank Sampah juga didirikan untuk mengubah sampah menjadi sesuatu yang lebih berguna dalam masyarakat, misalnya untuk kerajinan dan pupuk yang memiliki nilai ekonomis.

Bank Sampah adalah strategi untuk membangun kepedulian masyarakat agar dapat berkawan dengan sampah untuk mendapatkan manfaat ekonomi langsung dari sampah. Jadi bank sampah tidak dapat berdiri sendiri melainkan harus diintegrasikan dengan gerakan reduce,reuse dan recycle sehingga manfaat yang dirasakan bukan hanya pada bank sampah nya saja tapi juga warga serta masyarakat sekitar.

\section{PEMBERDAYAAN MASYARAKAT}

Menurut Robinson, menjelaskan bahwa pemberdayaan adalah suatu proses pribadi dan sosial, suatu pembebasan kemampuan pribadi, kompetensi, kreatifitas dan kebebasan bertindak. Sedangkan menurut Ife, mengemukakan bahwa pemberdayaan mengacu pada kata "empowerment" yang berarti memberi daya, memberi "power" (kuasa), kekuatan, kepada pihak yang kurang berdaya. ${ }^{3}$ Permasalahan lingkungan hidup terkait masalah-masalah ekologi, menurut Jim Ife dalam Community Development menyatakan bahwa permasalahan ekologi

3 Ife dan Frank Tesoriero. "Alternatif Pengembangan Masyarakat di EraGlobalisasi", Community Development (Yogyakarta: Pustaka Pelajar, 2008), 54. 
terdapat dua aspek penting. ${ }^{4}$ Adapun aspek tersebut, antara lain pertama suatu masyarakat berupaya untuk memecahkan permasalahan secara spesifik dengan solusi yang tepat. Kedua, mencari solusi dalam berbagai bidang kehidupan yang bisa saling terkait. Apabila kedua aspek tersebut dikaitkan dengan persoalan sampah, sehingga menimbulkan Bank Sampah yang bisa bermanfaat untuk lingkungan dan juga masyarakat.

Adapun usaha untuk meningkatkan pemberdayaan masyarakat bisa digolongkan dari beberapa aspek, pertama, menciptakan suasana yang bisa menimbulkan potensi dari masyarakat bisa berkembang. Fokusnya adalah setiap individu masyarakat memiliki potensi yang berkembang, artinya bahwa suatu masyarakat pasti memiliki sesuatu yang bisa dikembangkan, sehingga mempunyai kesempatan untuk mandiri. Pemberdayaan merupakan suatu upaya yang bertujuan untuk mendorong dan meningkatkan potensi yang dimiliki masyarakat untuk berkembang. Kedua, memperkuat potensi yang dimiliki oleh masyarakat. Hal ini dibutuhkan aksi yang nyata dari masyarakat itu sendiri agar bisa membuka peluang dalam melihat potensi yang dimiliki. Upaya pemberdayaan ini yakni meningkatkan taraf hidup bidang pendidikan,kesehatan, serta beberapa aspek yang bisa memajukan sumber perekonomian. ${ }^{5}$ Ketiga, pemberdayaan memiliki makna melindungi agar tidak semakin lemah oleh adanya pihak dari yang menindas. ${ }^{6}$

Menurut Agus Efendi terdapat tiga permasalahan pemberdayaan yang begitu kompleks, sehingga sangat dibutuhkan perjuangannya. ${ }^{7}$

4 Ife dan Tesoriero, 54.

5 Haryono Suyono, Pemberdayaan Masyarakat di Era Global (Bandung: Alfabeta, 2013), 55.

${ }^{6}$ Edi Suharto, Membangun Mesyarakat Memberdayakan Rakyat (Bandung: PT Rafika Aditama, 2009), 99.

7 Nanih Machendrawaty dan Agus Ahmad Safei. Pengembangan Masyarakat Islam dari Ideologi, Strategi Sampai Tradisi (Bandung: PT. Remaja Rosdakarya, 2001), 44. 
Pertama, pemberdayaan yang menyentuh aspek rohani. Pada saat ini kepribadian umat Islam terutama mayoritas kaum muda sangat begitu mudah terpengaruh oleh budaya barat, sehingga tidak jarang mereka tidak ingin belajar agama Islam. Kedua, pemberdayaan kecerdasan intelektual. Umat Islam di Indonesia dalam hal kemajuan teknologi sangat jauh tertinggal, maka dari itu dibutuhkan usaha pemberdayaan intelektual yang cerdas sebagai sebuah perjuangan baik di dunia maupun di akhirat. Ketiga, pemberdayaan ekonomi, permasalahan kemiskinan yang ada di Indonesia merupakan permasalahan yang serius, sehingga harus dicari solusi bukan untuk mengharap bantuan dari pihak lain. Setiap pribadi muslim diwajibkan untuk bekerja keras mencari rezeki di jalan Allah, baik bekerja ataupun membuka usaha.

\section{SEJARAH SINGKAT BANK SAMPAH SRIKANDI}

Pada umumnya bank adalah tempat menabung dalam bentuk uang dan kembali dalam bentuk uang juga. Sistem kerja Bank Sampah mengadopsi system bank pada umumnya. Bank Sampah ini hanya beda dalam bentuk tabungannya yang tidak lain sampah. Pengkorvensian tabungan sampah menjadi tabungan uang merupakan suatu bentuk perubahan yang ditawarkan oleh bank Sampah.

Bank Sampah Srikandi adalah sebuah lembaga yang bergerak dalam bidang pengelolaan sampah. Bank sampah sendiri merupakan salah satu tempat yang menjadikan sampah organik maupun anorganik sebagai alat transaksi antara nasabah dengan pengelola bank sampah. Bank sampah srikandi ini lahir karena adanya pemikiran dari Kepala Desa yang notabennya adalah seorang wanita. Pada awalnya beliau melihat bahwa ibu-ibu warga Candimulyo itu banyak yang nganggur karena tidak mempunyai pekerjaan tetap, kemudian beliau punya ide 
untuk mendirikan bank sampah supaya bisa memberdayakan ibu-ibu dengan kegiatan yang bermanfaat. Disamping itu beliau juga ingin memanfaatkan sesuatu yang kelihatannya tidak berharga bahkan membuat lingkungan tidak sehat menjadi sesuatu yang bernilai ekonomis. ${ }^{8}$

Timbunan sampah yang menumpuk setiap hari akan berakibat buruk bagi kesehatan lingkungan serta menimbulkan berbagai penyakit. Sampah rumah tangga merupakan penyumbang sampah terbesar, sementara Tempat Pembuangan Sampah (TPS) yang tersedia tidak akan bisa menampug sampah yang dihasilkan masyarakat secara terus menerus jika masyarakat tidak mulai bertindak untuk mengurangi sampah yang dihasilkan. Untuk itulah penanganan masalah sampah harus dimulai dari sumbernya. Bank sampah adalah suatu system pengelolaan sampah kering secara kolektif yang mendorong masyarakat untuk berperan aktif didalamnya. Sistem ini akan menampung, memilah dan menyalurkan sampah bernilai ekonomi pada pasar sehingga masyarakat mendapat keuntungan ekonomi dari menabung sampah.

Untuk membentuk bank sampah ada beberapa hal yang harus dilakukan'9, (1) Pemilahan sampah sesuai dengan jenisnya yang dilakukan sejak dari sumbernya (rumah tangga); (2) Tiap rumah memiliki sarana untuk mengumpulkan sampah kering, misalnya glansing atau plastik; (3) Menyediakan pengurus bank sampah; (4) Membuat kesepakatan jadwal penjualan; (5) Membuat sistem administrasi; (6) Memiliki pengepul dengan jadwal pengambilan rutin.

Dari sini akhirnya Kepala Desa Candimulyo mengadakan pelatihan tentang bank sampah dengan dibantu oleh pihak Lingkungan $2018^{\prime \prime}$

${ }^{8}$ Elya Widi Astuti, sebagai Lurah desa Candimulyo, “wawancara, 18 Nopember 9 Elya Widi Astuti, “wawancara, 18 Desember 2018” 
Hidup serta Pemerintah Pusat Bank sampah yang pesertanya melibatkan para warga Desa Candimulyo yang terdiri dari RW 01, RW 02, RW 03, RW 04 dan RW 05 terutama kaum wanita. Dari pelatihan-pelatihan ini akhirnya ibu-ibu semakin penasaran dan ingin mengetahui lebih lanjut tentang bank sampah. ${ }^{10}$

Akhirnya, pada tahun 2014 Kepala Desa membuat struktural organisasi pengelolaan, sistem bagi hasil dalam jual beli sampah warga dengan pengelola, serta pembukuan. Dan yang pertama menjadi penanggung jawab dalam bank sampah ini adalah ibu Kepala Desa sendiri yaitu Ibu Elya Widi Astuti. Sedangkan nama "Srikandi" sendiri dibuat karena yang mempunyai ide pertama yaitu seorang wanita atau srikandi yang tidak lain adalah Kepala Desa tersebut.

Selanjutnya Ibu Elya memberikan pengertian tentang sistemsistem yang diterapkan pada Bank Sampah Srikandi tersebut. Diantaranya yaitu bagaimana cara penabungan sampah di Srikandi serta bagi hasil antara warga dengan pengelola bank sampah. Akhirnya Bank Sampah Srikandi telah resmi dibuka. Dan Ibu Elya mengumpulkan warga RW 01 untuk merapatkan siapa saja yang berhak menjadi anggota ataupun nasabah di bank sampah tersebut. Kemudian diputuskan bahwa semua warga Desa Candimulyo berhak menjadi nasabah, Dan berhak memiliki buku tabungan. Dan selanjutnya warga diperbolehkan untuk menabung sampah organik maupun anorganik di bank sampah Srikandi. ${ }^{11}$

Tujuan dari didirikannya Bank Sampah Srikandi ini adalah pertama untuk memberi pengetahuan kepada warga masyarakat agar peduli terhadap kebersihan lingkungan, kedua memberi kegiatan yang bersifat ekonomi kepada ibu-ibu Rumah Tangga yang tidak mempunyai

10 Purwati, sebagai ketua dari Bank Sampah Srikandi, "wawancara, 18 Desember 2018".

${ }^{11}$ Elya, selaku Lurah sekaligus penanggung jawab Bank Srikandi, "wawancara, 5 Nopember 2018". 
pekerjaan, dan ketiga membiasakan masyarakat untuk memilah-milah sampah.

Sedangkan manfaat dari berdirinya Bank sampah srikandi ini12 adalah (1) Mengurangi jumlah sampah dilingkungan masyarakat; (2) Membuat lingkungan menjadi bersih, sehat, indah dan nyaman; (3) Memupuk kesadaran diri masyarakat akan pentingnya menjaga dan menghargai lingkungan hidup; (4) Membuka peluang bagi masyarakat untuk berkarya dengan membuat daur ulang sampah; (5) Menjadikan sampah sebagai tabungan yang mempunyai nilai ekonomi: (6) Menambah penghasilan masyarakat dari sampah-sampah yang dikumpulkan; (7) Membiasakan masyarakat agar suka menabung. (8) Menciptakan lapangan pekerjaan bagi masyarakat yang membutuhkan; (9) Mengentaskan kemiskinan; (10) Memberdayakan masyarakat terutama kaum ibu-ibu rumah tangga, karangtaruna dan para pelajar.

Dalam konsep Bank Sampah, bank menerima tabungan berupa sampah tetapi dapat kembali dalam bentuk uang sehingga mampu mengubah image sampah yang notabennya negatif menjelma menjadi sesuatu yang bernilai ekonomis. Perubahan nilai dari sampah ini tidak lepas dari sistem kerja yang diterapkan Bank sampah. Perubahan yang dilakukan Bank sampah tidak seutuhnya karena faktor ekonomi saja, melainkan peningkatan kesadaran lingkungan terhadap masyarakat.

Bank Sampah Srikandi mempunyai dua standart operasional dalam mengelola sampah sesuai dengan jenisnya, yaitu sampah anorganik dan sampah organik. Namun dalam Bank sampah srikandi ini banyak yang memilih program sampah anorganik karena mereka beranggapan bahwa sampah anorganik lebih menguntungkan dari pada sampah organik. Selain itu dari Bank Sampah pun juga jarang menerima

12 Tugiyani, salah satu nasabah dari Bank sampah srikandi, "wawancara, 18 Desember 2018". 
sampah organik, karena pengelolaannya yang sulit. Awal didirikannya Bank sampah ini sampah organik diproses menjadi pupuk, namun karena ada beberapa kendala dan hambatan akhirnya program berjalan kondisional, sesuai dengan kelonggaran dari pengelola.

Sedangkan dalam pengelolaan sampah anorganik, warga membawa sampah kepada tim pengelola Bank sampah kemudian sampah ditimbang, selanjutnya pengurus Bank sampah mencatat jumlah dari pengumpulan sampah tersebut dari masing-masing nasabah di buku besar dan buku tabungan masing-masing. Setelah proses ini selesai bagian operasional memilah sampah ke dalam 3 bagian yaitu pertama sampah yang bisa dijual, seperti besi, botol plastik, kardus dan lain-lain, kedua sampah yang bisa didaur ulang seperti stereofom, plastik sachet, sedotan, gelang aqua dan lain-lain, dan ketiga sampah yang tidak dapat didaur ulang kembali oleh Bank Sampah. Sampah yang dijual kembali akan dijual kepada pengepul yang merupakan mitra dari bank Sampah Srikandi. Sedangkan sampah yang bisa didaur ulang akan didaur ulang oleh ibu PKK Desa Candimulyo untuk dibuat kerajinan.

Selain menjual sampah kepada pengepul sampah yang menjadi mitra kerjasama, Bank sampah Srikandi juga mengolah kembali sampahsampah yang masih dapat dimanfaatkan menjadi berbagai macam produk yang mempunyai nilai ekonomi dan menguntungkan bagi pengelola Bank Sampah Srikandi.

1. Pupuk Kompos Dari Sampah Organik

Produk yang dihasilkan dari proses daur ulang sampah organik yaitu berupa pupuk kompos. Proses pembuatan yang lama dan rumit serta biaya yang mahal sedangkan pasca jualnya pun juga kurang menguntungkan, membuat produk ini tidak berlangsung lama.

2. Hasil Kerajinan Sampah Dari Botol plastik 
Produk yang dihasilkan dari proses daur ulang sampah plastik, seperti botol plastik, koran, sedotan, plastik bekas minuman biasanya dibikin vas bunga, tempat aqua, pigura, tas, dompet dan lain-lain. Produk-produk ini biasanya diikutkan dalam pameran-pameran atau bazar tingkat kecamatan atau kabupaten ataupun ketika ada kunjungan dari Team Lingkungan Hidup atau Team Adipura. Ibu-ibu pengelola Bank Sampah Srikandi ini juga sering diundang untuk mengisi pelatihan-pelatihan tentang pembuatan kerajinan tangan dari sampah bekas. Selain itu produk-produk dari bank sampah Srikandi ini juga sering diikutkan lomba kerajinan tingkat Kecamatan maupun Kabupaten.

\section{MAQASHID AL-SYARIAH}

Konsep maqashid al-Syari'ah sebenarnya telah dimulai dari masa Al-Juwaini yang terkenal dengan Imam Haramain dan oleh Imam alGhazali kemudian disusun secara sistimatis oleh seorang ahli ushul fikih bermadzhab Maliki dari Granada (Spanyol), yaitu Imam al-Syatibi (w. 790 H). Konsep itu ditulis dalam kitabnya yang terkenal, al-Muwwafaqat fi Ushul al-Ahkam, khususnya pada juz II, yang beliau namakan kitab alMaqashid. Menurut al-Syatibi, pada dasarnya syariat ditetapkan untuk mewujudkan kemaslahatan hamba (mashalih al-ibad), baik di dunia maupun di akhirat. Kemaslahatan inilah, dalam pandangan beliau, menjadi maqashid al-Syari'ah. Dengan kata lain, penetapan syariat, baik secara keseluruhan (jumlatan) maupun secara rinci (tafshilan), didasarkan pada suatu 'Illat (motif penetapan hukum), yaitu mewujudkan kemaslahatan hamba. ${ }^{13}$

II, 2-3.

${ }^{13}$ Syatiby, al-Muwafaqat fi Ushul al-Syari'ah, (Kairo: Mustafa Muhammad, ), jilid 
Untuk mewujudkan kemashlahatan tersebut al-Syatibi membagi Maqashid menjadi tiga tingkatan, yaitu: Maqashid dharûriyât, Maqashid hâjiyat, dan Maqashid tahsînât.Dharûriyât artinya harus ada demi kemaslahatan hamba, yang jika tidak ada, akan menimbulkan kerusakan, misalnya rukun Islam. Hâjiyât maksudnya sesuatu yang dibutuhkan untuk menghilangkan kesempitan, seperti rukhsah (keringanan) tidak berpuasa bagi orang sakit. Tahsiniat artinya sesuatu yang diambil untuk kebaikan kehidupan dan menghindarkan keburukan, semisal akhlak yang mulia, menghilangkan najis, dan menutup aurat. Dharuriyat beliau jelaskan lebih rinci mencakup lima tujuan, yaitu : (1) menjaga agama (hifzh ad-din); (2) menjaga jiwa (hifzh an-nafs); (3) menjaga akal (hifzh al-'aql); (4) menjaga keturunan (hifzh an-nasl); (5) menjaga harta (hifzh al-mal).14

Secara substansial maqasid al-syari'ah mengandung kemashlahatan, baik ditinjau dari maqasid al-syari' (tujuan Tuhan) maupun maqasid al-mukallaf (tujuan Mukallaf). $\underline{3}$ Dilihat dari sudut tujuan Tuhan, Maqasid al-Syariah mengandung empat aspek, keempat aspek inilah yang akan menjadi pokok pembahasan dalam makalah ini, (1). Tujuan awal dari Syari' (Allah dan rasul-Nya) menetapkan syariah yaitu untuk kemashlahatan manusia di dunia dan akhirat. (2). Penetapan syariah sebagai sesuatu yang harus dipahami. (3).Penetapan syariah sebagai hukum taklifi yang harus dilaksanakan. (4).Penetapan Syari'ah guna membawa manusia ke bawah lindungan hukum yakni terhindar dari mengikuti Hawa nafsu.

Secara bahasa Maqashid Syari'ah terdiri dari dua kata yaitu Maqashid dan Syari'ah. Maqashid berarti kesengajaan atau tujuan, Maqashid merupakan bentuk jama' dari maqsud yang berasal dari suku kata Qashada yang berarti menghendaki atau memaksudkan, Maqashid

14 Syatiby, 5. 
berarti hal-hal yang dikehendaki dan dimaksudkan. ${ }^{15}$ Sedangkan Syari'ah secara bahasa berarti المواضع تحدر الي الماءartinya Jalan menuju sumber air, jalan menuju sumber air dapat juga diartikan berjalan menuju sumber kehidupan. ${ }^{16}$

\section{MAQASHID AL-SYARI'AH MENURUT PARA AHLI}

1. Al-Imam Ghazali (Wafat th $505 \mathrm{H}$ )

Imam Al-Ghazali nama lengkapnya adalah Abu Hamid al-Ghazali lahir di Thusi yang merupakan murid dari Imam al-Haramain al-Juwaini. Al-Ghazali dikenal sebagai mujaddid terkemuka yang banyak menulis keilmua Islam seperti filsafat,fiqh,ushul fiqh, tasawuf dan displin ilmu lainnya.

Teori maqasid al-Syariah Al-Ghazali ditulis secara bertahap, mula-mula pada karya pertamanya Syifa al-Ghalil , kemudian dilanjutkan pada Ihya ulum al-din, dan disempurnakan dalam karya ushul fiqhnya yang berjudul al-Mustasfa fi Ilmi al-Ushul. Menurut al-Ghazali Maqasid yaitu "Penjagaan terhadap maksud dan tujuan syariat adalah upaya mendasar untuk bertahan hidup, menahan faktor-faktor kerusakan dan mendorong terjadinya kesejahteraan" Urutan maqashid al-Syariah Imam Al-Ghazali dibagi menjadi tiga, pertama al-dharuriyat (hak primer), kedua al-hajiyat (hak sekunder) dan ketiga al-Tahsiniyat (hak tersier).

2. Al-Imam al-Syatiby (Wafat th $790 \mathrm{H}$ )

Nama lengkapnya Ibrahim ibn Muhammad al-Gharanathi Abu Ishaq. Beliau menjadi masyhur karena dinilai berhasil mensistematisasikan teori Maqashid al-Syariah dalam karya al-

15 Ahmad Qorib, Ushul Fikih 2 (Jakarta: PT. Nimas Multima, 1997), 170. 140.

16 Fazlur Rahman, Islam, terj. Ahsin Muhammad ( Bandung: Pustaka, 1994), 
muwafaqat. Kandungan Kitab al-Muwafaqat al-Syathibi dibagi menjadi lima bagian (1) Al-Muqaddamat (premis-premis), (2) Al-Ahkam (hukumhukum), (3) Al-Maqasid (tujuan-tujuan syariat), (4) Al-Adilah (dalil-dalil), (5) Al-Ijtihad.

Tujuan-tujuan syariat dalam Maqasyid al-Syariah menurut alSyatibi ditinjau dari dua bagian. Pertama,berdasar pada tujuan Tuhan selaku pembuat syariat. Kedua berdasar pada tujuan manusia yang dibebani syariat. Pada tujuan awal yang pertama berkenaan dengan segi tujuan Tuhan dalam menetapkan prinsip ajaran syariat, dan dari segi ini Tuhan bertujuan menetapkannya untuk dipahami, juga agar manusia yang dibebani syariat dapat melaksanakan juga agar mereka memahami esensi hikmah syariat tersebut.

3. Ahmad al-Raysuni, "Maqasyid al-Syariah merupakan tujuan-tujuan yang telah ditetapkan oleh syariah untuk dicapai demi kemaslahatan manusia."

4. Abdul Wahab Khallaf, "Tujuan umum ketika Allah menetapkan hokum-hukum-Nya adalah untuk mewujudkan maksud Allah selaku pembuat syariah untuk memberikan kemaslahatan kepada manusia. Yaitu dengan terpenuhinya kebutuhan dharuriyah, hajiyah dan tahsiniyah agar manusia bias hidup dalam kebaikan dan dapat menjadi hamba Allah yang baik".

5. Imam Al-Syafi'i (Wafat th $204 \mathrm{H}$ )

Imam Al-Syafi'i adalah ulama' pertama yang mengaranag ilmu ushul fiqh. Imam Syafi;i adalah mutakallim yang (teolog) pertama yang mengkaji alasan ( $\left.t a^{\prime} l i l\right)$ tegaknya sebuah hokum, sedang illat sendiri merupakan bagian inti dari ilmu maqasid al-syari'ah. Imam Syafi'i adalah salah satu yang menaruh perhatian penting terhadap kaidah umum syariat dan maslahat terutama dalam praktek berijtihad dan penyimpulan sebuah hukum. Imam Syafi'i adalah ulama' yang 
menitikberatkan pada tujuan hokum (maqasid al-Ahkam) seperti dalam bersuci,puasa, haji, zakat, potong tangan (qashas), hokum pidaa ataupun dalam ranah maqasid yang lebih luas, seperti melindungi agama, jiwa, keturunan, harta dan lain sebagainya. ${ }^{17}$

6. Imam Al-Razy (Wafat th $606 \mathrm{H}$ )

Nama lengkap Imam Al-Razi adalah Fakhr al-Din al-Razi adalah seorang ulama ahli fiqh al-Syafi'i yang sangat proaduktif, telah menulis lebih dari 200 buku. Pemikiran maqashid al-syari'ah ar- Razi terangkum dalam karya al-mashul fi ilm al-Ushul al- Fiqh. Buku ini sangat penting karena meringkas tiga buku ushul klasik : al- Mu'tamad karya Abu alHasan al-Bashri, al-Burhan karya al-Juwaini dan al- Mustasfa karya alGhazali. ${ }^{18}$

Sumbangsih maqashid al-syariah al-Razi masih kental dengan warisan al- Ghazali seperti pada pembagian maslahah berikut contohcontoh yang dikemukakan. Hanya saja pada maslahah al-dharuriyah yang mencakup lima hal primer, yaitu jiwa, harta keturunan, agama dan akal, al-Razi memberi prioritas jiwa daripada agama. Urutan ini tentu tampak berbeda dengan gurunya, al-Ghazali yang lebih mendahulukan agama daripada jiwa.

\section{KONSEP PENJAGAAN AGAMA (HIFZ AL-DIN)}

Seperti yang kita ketahui bahwa agama adalah sesuatu yang sangat penting sebagai tolok ukur dalam setiap pemikiran dan tindakan. Keimanan kepada Allah sebagai sang Pencipta (Kholiq) alam semesta menjadikan setiap usaha atau perbuatan termasuk didalamnya tindakan ekonomi memperhatikna aturan-Nya, yaitu harus pada koridor halal dan 2000), 87

17 Muhammad Yusuf al-Badawi, Maqasid al-Syariah (Urdun: Dar al-Nafais,

18 al-Badawi, 82. 
beretika (thoyib).

Disisi lain keimanan seseorang juga menjadikan dia untuk percaya kepada hari kiamat sehingga segala tindakan dan usahanya dalam mencari rizki harus dilakukan dengan penuh tanggung jawab sesuai dengan norma-norma yang telah dirumuskan. Keimanan juga membawa seseorang untuk beramal sholeh denngan menjaga keharmonisan lingkungan atau memberi manfaat kepada orang lain. 19 Menurut Al-Syathibi menjaga agama sangat penting, menurut beliau penjagaan agama tidak hanya terkait tentang ibadah saja,tetapi meliputi menjaga hak-hak orang lain, menghormati agama dan kepercayaan orang lain dan tidak mengolok agama orang lain. ${ }^{20}$ Sedangkan menurut Umer Caphra, keimanan ditempatkan pada urutan pertama karena memberikan cara pandang dunia yang cenderung mempengaruhi kepribadian, yakni prilaku, gaya hidup, selera dan preferensi manusia, serta sikap-sikap terhadap manusia,sumber daya dan lingkungan. ${ }^{21}$

Berdasarkan hasil penelitian program pelayanan tabungan yang menggunakan prinsip mudharabah di Bank Sampah Srikandi pada umumnya membantu nasabah untuk mengamalkan ajaran agama Islam yakni ajaran yang sesuai dengan prinsip muamalah yaitu tidak melakukan transaksi yang mengandung riba. Hal ini jika dikaitkan dengan penjagaan agama, maka prinsip mudharabah yang diterapkan dalam Bank sampah Srikandi ini secara tidak langsung masuk ke dalam menjaga agama (hifdz al-Din).

19 Dawam Rahardjo, "Rancang Bangun Ekonomi Islam”, Makalah pada workshop Nasional Arsitektur Ekonomi Islam, UIN Syarif Hidayatullah, Jakarta, 28 Februari 2012, 15-16.

20 Jasser Auda, Membumikan Hukum Islam Melalui Maqasid al-Syari'ah, (Bandung: Mizan Media Utama, 2008), 56-59. Syariah, 124.

${ }^{21}$ Umar Chapra, The Islamic Vision of Development In The Light of Maqasid 


\section{PENJAGAAN JIWA (HIFZ AL-NAFS)}

Menurut Umer Chapra ${ }^{22}$ bahwa untuk memenuhi kesejahteraan, seseorang harus memiliki jiwa yang sehat agar dapat menjalankan syariat kehidupan. Begitupun menurut Al-Syathibi23 bahwa syariat wajib dilaksanakan bagi seseorang yang masih hidup sehat jasmani dan rohani. Maka jiwa yang sehat merupakan hal yang sangat penting dalam kehidupan sehingga dalam maqashid al-syariah ada penjagaan jiwa yang salah satunya dengan menjaga kesehatan.

Berkaitan dengan penjagaan jiwa ini, Bank Sampah Srikandi didirikan dengan tujuan memberdayakan warga yang belum mempunyai pekerjaan tetap juga kaum pemuda supaya tidak terjerumus kedalam hal-hal yang negatif. Hal ini menunjukkan bahwa tujuan didirikannya Bank Sampah Srikandi sesuai dengan tujuan syariah yaitu menjaga jiwa dengan membuka peluang pekerjaan bagi warga. Selain itu dengan adanya Bank Sampah,juga mengajak masyarakat untuk menjaga kebersihan lingkungan. Ketika lingkungan bersih dan sehat, maka akan sehat pulalah jasmani dan rohani manusia. Maka Bank Sampah Srikandi memenuhi prinsip dasar maqashid yaitu penjagaan jiwa (hifz al-nafs).

\section{PENJAGAAN AKAL (HIFZ AL-AQL)}

Menurut Rosbi Abd Rahman dan Sanep Ahmad, menjaga akal seperti menjauhi hal-24hal dapat menyebabkan hilangnya akal, seperti minuman keras. Menjaga akal juga bisa dengan menambah kemampuan

\footnotetext{
22 Chapra, 7.

23 Hamka Haq, Al-Syatibi Aspek Teologis Konsep Maslahah dalam Kitab Almuwaffaqat, 97.

${ }^{24}$ Rosbi Abd Rahman dan Sanep Ahmad, "Pengukuran Keberkesanan Agihan Zakat: Perspektif Maqashid al-Syariah", disampaikan dalam Seventh International Conference- The Tahwidi Epistemology : Zakat and Waqf Economy, Bangi 2010, 447-460
} 
akal dalam berpikir dengan jalan mencari ilmu pengetahuan seperti adanya majlis taklim atau kelompok-kelompok diskusi dan juga tersedianya fasilitas yang menunjang penjagaan akal seperti perpustakaan dan sarana pendidikan.

Terkait dengan Bank Sampah Srikandi, salah satu produknya yaitu simpan pinjam. Dalam program pinjaman ini nasabah bisa memanfaatkan untuk keperluan pendidikan, misalnya beli buku, beli laptop biaya masuk sekolah dan sebagainya.Program ini secara tidak langsung sudah memenuhi tujuan dari maqashid al-syariah. Tujuan selanjutnya yaitu memberdayakan masyarakat supaya mempunyai kegiatan dan mengurangi pengangguran. Hal ini juga memenuhi unsur dari maqashid al-syariah, yaitu melalui Bank sampah ini maka warga masyarakat mendapatkan kegiatan yang bermanfaat,mereka tidak melamun untuk hal-hal yang tidak berguna.

\section{PENJAGAAN KETURUNAN (HIFZ AL-NASL)}

Umar Chapra mengatakan bahwa kebijakan dalam penjagaan keturunan dibutuhkan agar tercipta generasi yang berkualitas dan berakhlak mulia pada masa yang akan datang. Untuk mencapai generasi berkualitas daapat terwujud melalui pernikahan dan keluarga yang berintegritas yaitu dengan kepastian kesehatan ibu dan gizi yang cukup bagi perkembangan anak pemenuhan kebutuhan hidup dengan kegiatan pembangunan yang berkelanjutan dengan penciptaan dan menjamin ketersediaan sumber daya ekonomi bagi generasi sekarang dan yang akan datang, lingkungan yang bersih dan sehat dengan konsep pembangunan ramah lingkungan dan berkelanjutan, terbebasnya dari konflik dan jaminan keamanan. ${ }^{25}$

${ }^{25}$ Umar Chapra, The Islamic Vision of Development In The Light of Maqasid 
Berdasarkan hasil penelitian dari sisi penetapan sasaran program dalam Bank Sampah Srikandi baik tabungan maupun pemberdayaan industri kreatif sasarannya adalah ibu-ibu rumah tangga, siswa sekolah dan karangtaruna ini sangat sesuai dengan konsep maqashid al-syariah yakni menjaga keturunan, karena sasarannya tepat dan berkesinambungan. Semua wajib menjaga lingkungan supaya tetap bersih, indah dan rapi.

\section{PENJAGAAN HARTA (HIFZ AL-MAL)}

Penjagaan harta dalam konsep maqashid al-syariah yaitu pengembangan kemampuan memperoleh harta sebagai sarana kehidupan didunia dan akhiratserta dapat memanfaatkannya untuk kesejahteraan sesama manusia. Menghilangkan kesenjangan antar kelas ekonomi dengan mengembangkan memperoleh pendapatan. ${ }^{26}$ Menurut Umar Chapra, harta merupakan kebutuhan yang sangat penting untuk memenuhi keempat maqashid al-syariah sehingga penjagaan harta sangatlah penting. ${ }^{27}$

Dari hasil penelitian bahwa tujuan program pemberdayaan adalah meningkatkan perekonomian masyarakat dan mengurangi pengangguran serta mengurangi sampah yaitu dengan pelatihan daur ulang sampah dan pengembangan jiwa wirausaha dengan peminjaman modal. Dalam konsep maqashid al-syariah ini maksud dalam kategori penjagaan harta (hifz al- mal).

26 Jasser Auda, Membumikan Hukum Islam Melalui Maqasid al-Syari'ah, 58.

27 Umar Chapra, The Islamic Vision of Development In The Light of Maqasid Syariah, 7. 


\section{KESIMPULAN}

Hukum Islam dibuat dengan tujuan untuk mewujudkan kemaslahatan manusia baik di dunia maupun diakhirat. Dalam rangka mewujudkan kemashlahatan dunia dan akhirat itulah, maka para ulama Ushul Fiqh merumuskan tujuan hukum Islam tersebut kedalam lima misi/tujuan yang harus dipelihara untuk melestarikan dan menjamin terwujudnya kemashlahatan. Kelima tujuan tersebut tertuang dalam Maqashid al-Syari'ah yaitu memelihara agama, jiwa, aqal, keturunan dan harta. Maqashid al-syariah yaitu konsep untuk mengetahui hikmah ditetapkannya suatu hukum terhadap manusia, dan tujuan akhir hukum tersebut adalah satu, yaitu mashlahah atau kebaikan dan kesejahteraan umat manusia baik didunia (dengan Mu'amalah) maupun di akhirat (dengan 'aqidah dan Ibadah).

Bank Sampah Srikandi adalah suatu bank yang melayani simpan pinjam berupa sampah yang tujuannya adalah untuk mengurangi jumlah sampah demi kenyamanan lingkungan. Selain itu juga menyulap sampah menjadi sesuatu yang berharga yang benilai ekonomi. Tujuan selanjutnya yaitu memberdayakan masyarakat supaya mempunyai potensi yang bagus sehingga akan mengurangi pengangguran dan menjadikan manusia yang berguna dan bermanfaat bagi sesame. Dari penelitian ini bisa disimpulkan bahwa Bank Sampah Srikandi yang berada di Dolopo ini memenuhi konsep maqashid al-syariah, yaitu bahwa didirikannya Bank sampah tersebut bertujuan untuk kemaslahatan manusia.

\section{DAFTAR PUSTAKA}

Auda, Jasser. Membumikan Hukum Islam Melalui Maqasid al-Syari'ah. Bandung: Mizan Media Utama, 2008.

Al-Badawi, Muhammad Yusuf. Maqasid al-Syariah. Urdun: Dar al-Nafais, 2000. 
Astuti, Elya Widi, "wawancara sebagai Penanggung jawab Bank Sampah Srikandi, 18 Desember 2018"

Chapra, Umar. The Islamic Vision of Development In The Light of Maqasid Syariah.

Ife dan Frank Tesoriero. "Alternatif Pengembangan Masyarakat di EraGlobalisasi", Community Development. Yogyakarta : Pustaka Pelajar, 2008.

Machendrawaty, Nanih dan Agus Ahmad Safei. "Pengembangan Masyarakat Islam, Dari Ideologi, StrategiSampai Tradisi Bandung: PT. Remaja Rosdakarya, 2001.

Peraturan Menteri Negara Lingkungan Hidup Republik Indonesia Nomor 13 tahun 2012 tentang Pedoman Pelaksanaan Reduce, Reuse, dan Recycle Melalui Bank Sampah.

Qorib, Ahmad. Ushul Fikih 2. Jakarta: PT. Nimas Multima, 1997.

Rahardjo, Dawam. "Rancang Bangun Ekonomi Islam." Makalah pada workshop Nasional Arsitektur Ekonomi Islam, UIN Syarif Hidayatullah, Jakarta, 28 Februari 2012.

Rahman, Rosbi Abd dan Sanep Ahmad. "Pengukuran Keberkesanan Agihan Zakat: Perspektif Maqashid al-Syariah", disampaikan dalam Seventh International Conference- The Tahwidi Epistemology : Zakat and Waqf Economy, Bangi 2010.

Rahman, Fazlur. Islam, terj. Ahsin Muhammad. Bandung: Pustaka, 1994.

Suharto, Edi. "Membangun Mesyarakat Memberdayakan Rakyat. Bandung: PT Rafika Aditama, 2009.

Suyono, Haryono. Pemberdayaan Masyarakat di Era Global. Bandung: Alfabeta, 2013.

Tugiyani, "wawancara sebagai nasabah Bank Sampah Srikandi, 18 Desember 2018"

Unilever indonesia, buku panduan sistem bank sampah dan 10 kisah sukses. Jakarta: unilever, 2014. 